\title{
Depressive Symptoms, Anxiety, Self-Esteem and Educational Social Skills in Public School Teachers
}

\author{
Tainá Katiúcia Simore Simor¹, Vinícius Renato Thomé Ferreira², Naiana Dapieve Patias ${ }^{3}$, \\ Márcia Fortes Wagner ${ }^{2}$, Vanessa Rissi' ${ }^{2}$, Tainan Nascimento ${ }^{1}$
}

\author{
${ }^{1}$ Private Office, Passo Fundo, Brazil \\ ${ }^{2}$ Psychology Program at IMED, Passo Fundo, Brazil \\ ${ }^{3}$ Psychology Program at Federal University of Santa Maria (UFSM), Santa Maria, Brazil \\ Email: vinicius.ferreira@imed.edu.br
}

How to cite this paper: Simor, T. K. S., Ferreira, V. R. T., Patias, N. D., Wagner, M. F., Rissi, V., \& Nascimento, T. (2019). Depressive Symptoms, Anxiety, Self-Esteem and Educational Social Skills in Public School Depressive Symptoms, Anxiety, Self-Esteem and Educational Social Skills in Public School Teachers. Creative Education, 10, 3469-3482.

https://doi.org/10.4236/ce.2019.1013267

Received: November 8, 2019

Accepted: December 21, 2019

Published: December 24, 2019

Copyright $\odot 2019$ by author(s) and Scientific Research Publishing Inc. This work is licensed under the Creative Commons Attribution International License (CC BY 4.0).

http://creativecommons.org/licenses/by/4.0/

\begin{abstract}
Depression and anxiety symptoms are increasingly common in the world population and may damage different aspects of life. In the school context, these symptoms may affect teachers' self-esteem and educational social skills. This study aimed to evaluate and compare depression and anxiety symptoms, self-esteem and educational social skills in first and last grades elementary public school teachers, with 196 teachers, men and women, aged 18 years or older. The instruments applied were: a sociodemographic questionnaire, State-Trait Anxiety Inventory (STAI), Population Screening Scale for Depression Epidemiological Studies Center (CES-D), Depressive Symptoms Intensity Survey (LIS-D), the Anxiety Symptoms Intensity Survey (LIS-A), the Rosenberg Self-Esteem Scale (RSES), and the Inventory of Educational Social Skills-Teachers (IHSE). The main results indicate differences between the two teachers' groups regarding the levels of depressive and anxiety symptoms, some educational social skills and self-esteem. Future studies with teachers should consider specific aspects of teaching work.
\end{abstract}

\section{Keywords}

Depression Symptoms, Anxiety Symptoms, Self-Esteem, Teachers, Educational Social Skills

\section{Introduction}

Elementary school teachers play an important role in individuals' development (Leite \& Colombo, 2008; Lessa, Felicio, \& Almeida, 2017). At the same time, in their occupational setting, they may face low recognition and low payment, violence, work overload, and scarce material resources to professional exercise. 
This context is especially common in the public schools, where it is difficult to find proper working conditions due to poor investment management (Gasparini, Barreto, \& Assunção, 2006; Levy, Nunes Sobrinho, \& Souza, 2009; Salgado Junior \& Novi, 2016; Freitas \& Knives, 2013). These aspects affect teachers' work and health (Freitas \& Knives, 2013; Rodrigues \& Santos, 2017), and may increase the risk of cardiovascular disease, repetitive strain injuries (RSI), depression and anxiety (Freitas \& Knives, 2013), and decrease self-esteem.

An adverse work context is a risk factor for the onset of depressive symptoms in teachers (Silva \& Guillo, 2015; Diehl \& Marin, 2016; Miranda, 2017). The prevalence of this symptomatology can reach $23 \%$ in this population (Silva, Bolsoni-Silva, \& Loureiro, 2018), jeopardizing the successful performance of work activities (Serafim \& Saffi, 2015). The most common symptoms are depressed mood, decreased pleasure when doing something, weight loss or gain (more or less than 5\% weight after one month without a specific diet), insomnia or hypersomnia, psychomotor agitation or retardation, fatigue or energy loss, feelings of worthlessness or extreme guilt, reduced ability to think or concentrate, and recurrent thoughts of death, related to fear of dying and/or suicidal ideation, with or without specific planning (American Psychiatric Association [APA], 2014; Sadock, Sadock, \& Ruiz, 2016).

Anxiety symptoms can also affect teacher's work, and are characterized by the anticipation of something dangerous, a future threat, causing emotional and behavioral reactions that include: vertigo, diarrhea, hyperhidrosis (exaggerated sweat), increased reflexes, palpitations, dilated pupil, restlessness, syncope (loss of consciousness due to decreased cerebral blood flow), tachycardia, extremities tingling sensation, tremble, stomach upset, frequency, hesitation and urinary urgency (APA, 2014; Sadock, Sadock, \& Ruiz, 2016). When teachers are exposed to risk situations, anxiety symptoms may appear, affecting their work and self-esteem (Batista, Carlotto, \& Moreira, 2013; Sadock, Sadock, \& Ruiz, 2016; Pinheiro, Sousa, Feitosa, \& Batista, 2017). It is possible to found this symptomatology in more than $70 \%$ of a public school teacher sample (Tostes, Albuquerque, Silva, \& Petterle, 2018).

In contrast to depression and anxiety symptoms, high levels of self-esteem may be a sign of good mental health in teachers because they can increase motivation, perception of success and engagement in work activities, reducing irrational beliefs and perceived failure (Mosquera \& Stobäus, 2006; Pedro \& Peixoto, 2006). Self-esteem can be defined as the value given to oneself and can be a protective element against depressive symptoms. People with high self-esteem can act better in different situations (Hutz \& Zanon, 2011). In the field of education, the relationship between teacher and student can affect self-esteem (Mosquera \& Stobäus, 2006; Ferreira \& Moreira, 2010).

Depression, anxiety symptoms and self-esteem may also be associated with teachers' social skills (Fernandes, Falcone, \& Sardinha, 2012), whose can be defined as the individual competences that should be used facing the demands 
imposed by given social contexts (Caballo \& Claudino, 2007; Del Prette \& Del Prette, 1999). Specifically, educational social skills (ESS) are a set of skills that must be practiced in the teaching and learning context. Mastering specific social skills is indispensable in any profession, especially teaching children (Silva, Aznar-Farias, \& Silvares, 2009; Reis, Prata, \& Soares, 2012; Rosin-Pinola, Marturano, Elias, \& Del Prette, 2017). When teachers can manage their activities, they can also share the academic program with the students, increasing the effectiveness of the social interactions in the classroom (Lessa, Felicio, \& Almeida, 2017).

Possible classifications of ESS include 1) Communication, Expressiveness, Coping, and 2) Setting Boundaries. In the ESS of Communication, the teacher must realize the exact moment-as well as the mood, place and time-to start and end an effective conversation with students, aiming at a satisfactory teaching and learning process. In the ESS of Expressiveness and Coping, the teacher must know how to express affection through gestures and words, to praise at the appropriate time and to deal with different points of view. The ESS of setting boundaries, in turn, requires the development of skills to deal with criticism, to stipulate rules, to deny some students' requests, to know how to recognize mistakes, to apologize and take precautionary measures to avoid some behavioral issues (Bolsoni-Silva, 2010).

Improvement in social skills has several benefits that impact the classroom setting: it can help to avoid violent situations (Huang, Eddy, \& Camp, 2017), to reduce the cases of bullying (Pyhältö, Pietarinen, \& Soini, 2015), and to improve teacher confidence (Van Maele \& Van Houtte, 2009). Besides, better ESS can help leadership skills in school, supporting teaching and learning (Kraft, Marinell, \& Shen-Wei Yee, 2016), increasing academic achievement (Senler, 2016) and student support (Bartram \& Bailey, 2009; Cornell, Shukla, \& Konold, 2016).

In elementary school, there are differences between the teacher's work in the first and last grades, and one of the reasons for this difference is the evolutionary stage in which children are. In the first grades, there is one teacher for each class, which can increase the workload, while in the last grades there are several teachers who share the responsibility for teaching (Monteiro \& Teixeira, 2004a; 2004b; Ramos \& Rosa, 2008; Rosa, Perez, \& Drum, 2007). Working with younger children requires more teachers' caution and care. Besides, first grades' teachers also need to implement more interactive and playful teaching methods, because the traditional methodology may prove counterproductive to transmit the academic program to first graders of elementary school. This kind of demand can take teachers out of their comfort zone, requiring different skills to implement this new methodology. At the same time, this can bring concern and anxiety because teachers do not know if they will be able to perform these activities properly (Leite \& Carneiro, 2019).

Teaching and learning processes can be influenced by the teacher's performance in the school context. Therefore, the aims of this study were: to assess the prevalence of depression and anxiety symptoms, self-esteem, and ESS in ele- 
mentary public-school teachers; to compare these variables between first and last grade teachers, and to verify whether there is an association between these variables and ESS.

\section{Method}

\subsection{Sample}

A total of 196 elementary school teachers participated in the study, being 180 women $(91.8 \%)$ and 16 men $(8.2 \%)$, aged 23 to 71 years $(M=46.91$; $S D=7.64)$. All of them were from the public-school system of a southern city in Brazil. The sample was divided into two groups: Group A, first grades teachers ( $n=130$, $66.3 \%$ ) and Group B, final grades teachers $(n=66,33.7 \%)$. The criteria for inclusion in the study were: teachers from the municipal school system, aged 18 years or older, with teaching experience, currently working in class, and who agreed to participate in the research. Teachers who agreed to participate, signed the Free and Informed Consent (TCLE) but declared that they did not have hours of professional activity in the classroom were excluded from de research.

\subsection{Instruments}

Sociodemographic data questionnaire: includes questions regarding participants' sociodemographic characteristics, such as gender, age, education level, marital status, and others.

State-Trait Anxiety Inventory (STAI): it is composed of 20 statements that assess anxiety state (A-state) and anxiety trait (A-trait) through questions about how the individual feels generally. This instrument showed internal consistency (Cronbach's alpha) for the Brazilian sample ranging from 0.83 to 0.87 (Biaggio, Natalício, \& Spielberger, 1977).

Population Screening Scale for Depression Epidemiological Studies Center (CES-D): 20 questions explore positive affect, depression, somatic/reduced activity, and interpersonal problems using a 4-point Likert scale. The Brazilian version showed Cronbach's alpha of 0.87 (Silveira \& Jorge, 1998).

Depressive Symptoms Intensity Survey (LIS-D): 35 questions (initial version), displayed on a 5-point Likert scale, assesses the intensity of depressive symptoms. Four dimensions of the survey were used: affective, behavioral, somatic symptoms, and thinking. Reliability studies have indicated a Cronbach's alpha of $\alpha=0.9$ and a stability of 0.76 (Ferreira, 2012).

Anxiety Symptoms Intensity Survey (LIS-A): 34 questions (initial version) assess the intensity of anxiety symptoms on a 5-point Likert scale. Previous studies showed a reliability of 0.9 (Cronbach's alpha) (Ferreira, 2015).

Rosenberg Self-Esteem Scale (RSES): evaluates general self-esteem and consists of 10 sentences, displayed on a 4-point Likert scale. The final score ranges from 10 to 40 points. This scale showed a Cronbach's alpha of 0.9 (Brazilian version, Hutz, Zanon, \& Vazquez, 2014).

Inventory of Educational Social Skills-Teachers: (IHSE; Del Prette \& Del 
Prette, 2013): 64 self-report items arranged on a 5-point Likert scale. It consists of two subscales: Subscale 1, called Organize Interactive Activity, contains 14 items that provide a total score (Cronbach's alpha of 0.957) and three-factor scores (Principal Axis Factoring, with PROMAX rotation). Subscale 2, called the Ability to Conduct Interactive Activity, contains 50 items that provide a total score (Cronbach's alpha 0.948), and four-factor axes (Principal Axis Factoring), with PROMAX rotation. At the end of the instrument, seven items are presented, which should be answered on a scale ranging from -5 to 5 (Del Prette \& Del Prette, 2013).

\subsection{Procedures}

This study was approved by an ethical research committee, recognized by the National Health Council (CNS) under the number 2014441, funded by CNPq (edict 421252/2016-2). In the beginning, the researchers contacted the education department to present the project and obtain authorization for the research. After authorization from the secretary of education, the researchers called the schools' principals and invited them to participate in the survey. Those who accepted the invitation attended a meeting with teachers during working time to present the research project, the objectives, and the ethical issues. At this meeting, the researchers explained that the research is part of a larger project consisting of several steps. After the explanation, the present teachers were invited to participate in the study and those who accepted, signed the Free and Informed Consent (TCLE) and fulfill the instruments. In the end, the instruments were collected and data compilation started for statistical analysis.

\subsection{Data Analysis}

Data were analyzed using descriptive and inferential statistics. Tables were developed for sample characterization and for organizing the scores obtained from the instruments. The Mann-Whitney nonparametric test was used to compare the performance between first grades (first to fourth grade) teachers and last grades (fifth to ninth grade) teachers. This test is indicated for ordinal data analysis, dismissing normal distribution. Spearman correlation was employed, considering: perfect correlation $=$ values of 1 and -1 ; weak correlation $=0.3$ to 0.1 and -0.3 to -0.1 ; moderate correlation $=0.6$ to 0.4 and -0.6 to -0.4 ; and strong correlation $=$ values from 0.9 to 0.7 and -0.9 to -0.7 (Dancey \& Reidy, 2013).

\subsection{Ethical Issues}

Participants received clarification about: the confidentiality of their personal information, the possibility of withdrawal if they felt uncomfortable, and voluntary and free participation. All who agreed to participate in the research signed the Free and Informed Consent (TCLE), according to Resolution 466/2012 of the Brazilian Ministry of Health. 


\section{Results}

The sample consisted of 196 teachers. 113 (57.7\%) were 46 years or older and 67 (34.2\%) were between 36 and 45 years old. 124 (63\%) teachers were married or had a stable union and $170(86.7 \%)$ attended the Christian religion. $83(42.3 \%)$ participants received 3 to 6 minimum wages, $129(65.8 \%)$ had 15 or more years of profession and $76(38.8 \%)$ worked at that school for a period of up to four years and 11 months.

First grades teachers (Group A) presented higher rates of depression and anxiety symptoms. According to CES-D, depressive symptoms were below the cut-off point 16, which indicates the presence of this symptom (Silveira \& Jorge, 1998 ), although without statistically significant difference between groups ( $p=$ $0.10)$. The LIS-D pointed out that Group A presented higher depressive symptoms in affective $(p=0.04)$ and somatic $(p<0.01)$ symptoms and the total score $(p=0.01)$ when compared with last grades teachers (Group B).

Group A also achieved higher scores on both LIS-A and STAI, but with no statistically significant differences. In the STAI, 40 or more points indicate the presence of anxiety symptoms (Moreira, Melo, Tomaz, \& Azevedo, 2006).

The self-esteem assessment by the RSES indicated a general mean slightly higher than the mean of the general population, which is 32.9 points (Hutz, Zanon, \& Vazquez, 2014). The highest self-esteem score was found in Group B, presenting a statistically significant difference $(p=0.04)$.

The Educational Social Skills Inventory (IHSE) indicated higher ESS scores in Group A, in most factors and the total score. The factors "Choose and make available materials and content", "Organizing physical environment" and "Cultivating affection, support and good mood" achieved higher scores in Group A, with a statistically significant difference. The factors "Giving instruction on activities" and "Approve and value behaviors" were higher in Group B, but with no statistically significant difference (Table 1).

Spearman's correlations between the LIS-D dimensions, the CES-D, and the LIS-A and STAI questionnaires presented positive and moderate/strong correlations with each other, with rho $(\rho)$ between 0.477 and 0.759 . RSES showed moderate negative correlations with depressive symptoms (total LIS-D, $\rho=-0.581$; CES-D, $\rho=-0.616$ ) and anxiety symptoms (LIS-A, $\rho=-0.596$; STAI, $\rho=$ $-0.596)$. In addition, weak positive correlations were found between IHSE and the self-esteem factors "Cultivating affection, support and good mood" (E2F1, $\rho$ $=0.202$ ), "Approve and value behaviors" (E2F3, $\rho=0.272)$, "Disapprove, restrict and correct behaviors" (E2F4, $\rho=0.163)$ and the total score $(\rho=0.178)$. On the other hand, the correlations between symptoms of depression and anxiety were positive, weak and with no statistical significance (Table 2).

\section{Discussion}

The depressive symptoms indicated by CES-D presented a mean compatible with that found in the general population (Silveira \& Jorge, 1998), and without 
T. K. S. Simor et al.

Table 1. Participants performance in the instruments.

\begin{tabular}{|c|c|c|c|c|c|c|c|c|c|}
\hline \multirow{2}{*}{ Instrument } & \multirow{2}{*}{ Factor } & \multicolumn{2}{|c|}{ Total } & \multicolumn{2}{|c|}{ First grades } & \multicolumn{2}{|c|}{ Last grades } & \multicolumn{2}{|c|}{ Mann-Whitney } \\
\hline & & Mean & SD & Mean & SD & Mean & SD & $\mathrm{U}$ & $p$ \\
\hline \multirow[t]{3}{*}{ CES-D } & Total & 15.45 & 9.56 & 15.88 & 9.56 & 13.55 & 8.55 & 3668.5 & 0.10 \\
\hline & Affective & 6.28 & 4.56 & 6.70 & 4.80 & 5.14 & 3.55 & 3498 & 0.04 \\
\hline & Behavioral & 6.63 & 3.88 & 6.67 & 3.84 & 6.23 & 3.79 & 3996 & 0.48 \\
\hline \multirow[t]{3}{*}{ LIS-D } & Thinking & 4.55 & 3.50 & 4.74 & 3.67 & 3.89 & 2.93 & 3755.5 & 0.18 \\
\hline & Somatic & 8.38 & 4.66 & 9.23 & 4.63 & 6.59 & 4.25 & 2877.5 & $<0.01$ \\
\hline & Total & 25.84 & 13.57 & 27.35 & 13.77 & 21.86 & 11.64 & 3267 & 0.01 \\
\hline LIS-A & Total & 30.62 & 19.41 & 31.63 & 19.46 & 28.22 & 17.97 & 3730 & 0.18 \\
\hline STAI & Total & 38.33 & 10.39 & 38.52 & 10.00 & 37.09 & 9.76 & 3783 & 0.23 \\
\hline \multirow[t]{4}{*}{ RSES } & Total & 33.59 & 4.04 & 33.31 & 4.18 & 34.39 & 3.59 & 3538.5 & 0.04 \\
\hline & E1F1 & 19.83 & 3.39 & 19.79 & 3.62 & 20.03 & 2.93 & 4146.5 & 0.77 \\
\hline & E1F2 & 10.18 & 3.63 & 10.63 & 3.40 & 9.38 & 3.99 & 3453.5 & 0.03 \\
\hline & E1F3 & 10.95 & 3.09 & 11.47 & 2.96 & 10.00 & 2.99 & 2989.5 & $<0.01$ \\
\hline \multirow{5}{*}{ IHSE } & E2F1 & 42.61 & 7.73 & 43.39 & 7.93 & 41.55 & 6.96 & 3515 & 0.05 \\
\hline & $\mathrm{E} 2 \mathrm{~F} 2$ & 38.58 & 8.27 & 39.21 & 8.54 & 37.67 & 7.19 & 3648.5 & 0.10 \\
\hline & E2F3 & 31.81 & 4.72 & 31.75 & 4.63 & 32.06 & 5.05 & 4060 & 0.72 \\
\hline & E2F4 & 42.08 & 6.92 & 42.28 & 6.99 & 41.91 & 6.70 & 4009.5 & 0.51 \\
\hline & IHSE total & 195.89 & 30.94 & 198.52 & 32.23 & 192.59 & 25.92 & 3529 & 0.05 \\
\hline
\end{tabular}

Note: CES-D = Population Screening Scale for Depression Epidemiological Studies Center; LIS-D = Depressive Symptoms Intensity Survey; LIS-D: Affective = Affective symptoms; Behavior = Behavior symptoms; Thinking = Thinking; Somatic = Somatic symptoms; LIS-A = Anxiety Symptom Intensity Survey; STAI = State-Trait Anxiety Inventory; RSES = Rosenberg Self-Esteem Scale; IHSE = Inventory of Educational Social Skills-Teachers; IHSE: E1 = Organize interactive activity; E1F1 = Giving instruction on activities; E1F2 = Choose and make available materials and content; E1F3 = Organizing physical environment; E2 = Conduct interactive activity; E2F1 = Cultivating affection, support and good mood; E2F2 = Present, explain and evaluate interactively; E2F3 = Approve and value behaviors; E2F4 = Disapprove, restrict and correct behaviors. Source: Primary.

statistically significant difference between the teachers groups. LIS-D doesn't have normative data yet, however, it indicated scores with an average similar to that found in the general population (Mean $=23.77$; Ferreira, unpublished), suggesting that the prevalence of depressive symptoms in this sample is similar to the prevalence in general population. The results of the LIS-D showed a statistically significant difference between the two groups in the total score, in the affective symptoms and somatic symptoms: the first grades teachers showed higher score (greater symptoms) than the final grades teachers. In the last grades of elementary school, there is usually one teacher to educate each subject, while in the first grades only one teacher is responsible for teaching all educational content. Moreover, in the early grades, the teacher spends more time with his students, which can bring their relationship closer while maximizing some negative work aspects. In the last grades, responsibility for students' performance is distributed 
Table 2. Correlations between depression and anxiety symptoms, self-esteem and educational social skills.

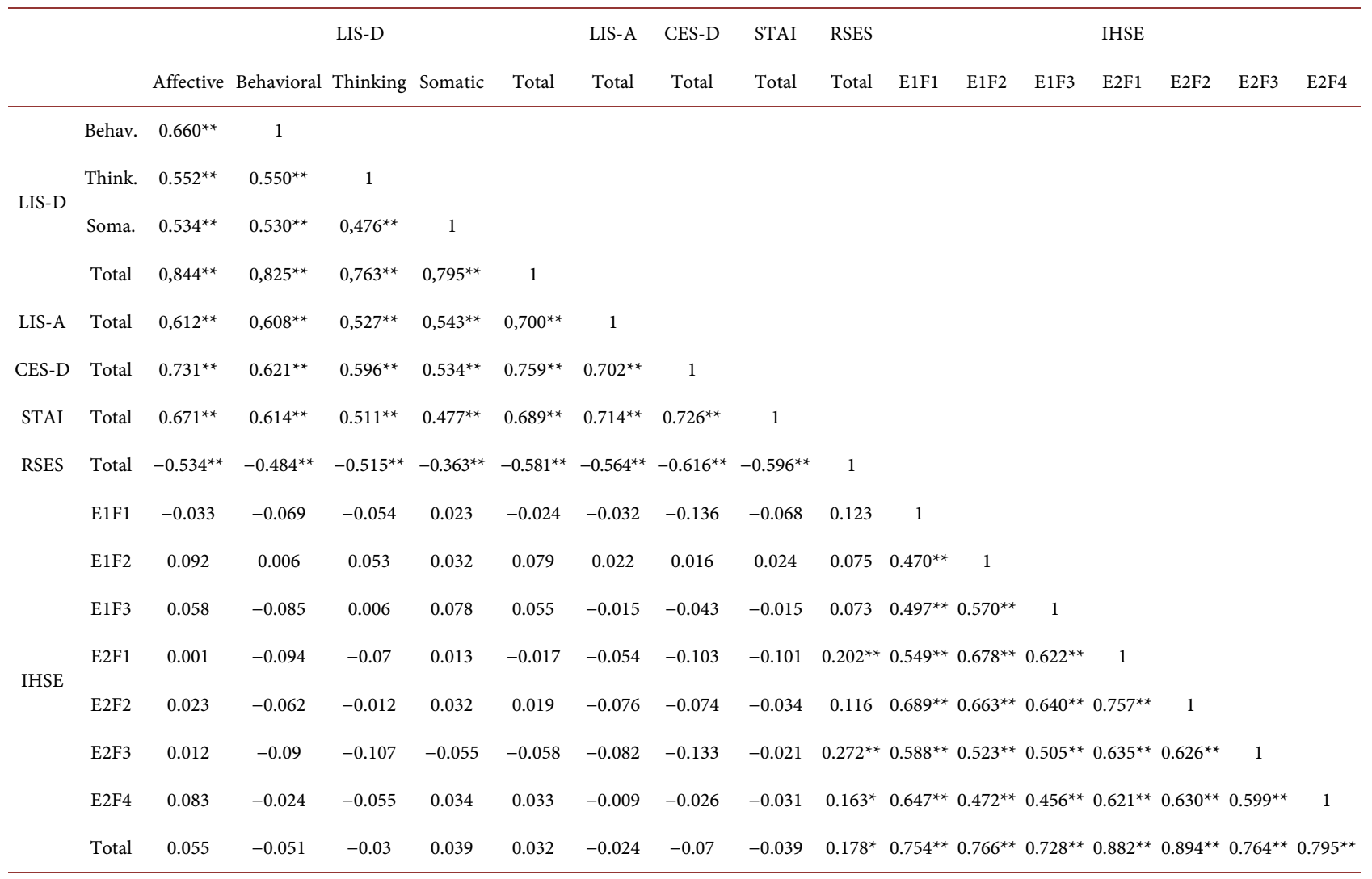

Note: ${ }^{*}$ Correlation is significant at the 0.01 level (two-tailed). ${ }^{*}$ Correlation is significant at the 0.05 level (two-tailed). LIS-D = Depressive Symptoms Intensity Survey; LIS-D: Affective = Affective symptoms; Behav. = Behavior symptoms; Think. = Thinking; Soma. = Somatic symptoms; LIS-A = Anxiety Symptom Intensity Survey; CES-D = Population Screening Scale for Depression Epidemiological Studies Center; STAI = State-Trait Anxiety Inventory; RSES = Rosenberg Self-Esteem Scale; IHSE = Inventory of Educational Social Skills - Teachers; IHSE: E1 = Organize interactive activity; E1F1 = Giving instruction on activities; E1F2 = Choose and make available materials and content; E1F3 = Organizing physical environment; E2 = Conduct interactive activity; E2F1 = Cultivating affection, support and good mood; E2F2 = Present, explain and evaluate interactively; E2F3 = Approve and value behaviors; E2F4 = Disapprove, restrict and correct behaviors. Source: Primary.

among different teachers of the same class. However, in the first grades, this responsibility is entirely assigned to a single teacher (Rodrigues \& Ferreira, 2016; Ramos \& Rosa, 2008; Rosa, Perez, \& Drum, 2007; Monteiro \& Teixeira, 2004a; 2004b). This may cause increased pressure and demand, raising the vulnerability of first grades teachers to develop depressive symptoms.

Anxiety scores did not differ between groups, although first grades teachers had higher scores. The prevalence in the sample of this study corresponds to the prevalence in the general population. On the other hand, the self-esteem score was significantly higher in Group B and slightly above that found in the general population (Hutz \& Zanon, 2011; Hutz, Zanon, \& Vazquez, 2014). This outcome may be explained considering the possible good working conditions in the studied sample, favoring low anxiety scores. Institutional and interpersonal relationships, individual achievement and stability have a modest impact on self-esteem, while relationships with students most strongly influence teachers' self-esteem (Pedro \& Peixoto, 2006). Group A teachers may be subjected to institutional factors that increase anxiety, such as greater concerns about younger students' classes. Self-esteem is the individuals' ability to evaluate themselves po- 
sitively or negatively, whereas depressive symptoms cause negative feelings about everything and themselves (Silva, 2006; Manso \& Matos, 2006; Castro et al., 2010; Dalgalarrondo, 2019; Teixeira, Nunes, Ribeiro, Arbinaga, \& Vasconcelos-Raposo, 2016; Kernis, 2005). In this study, moderate and negative correlations were identified between depression and anxiety symptoms and self-esteem. In other words, the higher the levels of depression and anxiety symptoms, the lower the self-esteem. These findings conform to the literature, once depression and anxiety symptoms can decrease life satisfaction and quality of life (Streider, 2009).

The IHSE results identified a higher score from Group A in "Choose and making available materials and content", "Organizing the physical environment", "Cultivating affection, support and good mood" and in the total IHSE score, with a statistically significant difference compared to Group B. Appropriate choice of teaching supplies is essential in all age groups, and the younger the students, the more important this selection is. Teachers shall provide suitable and stimulating materials, including activities that can prompt interest and attract students' attention, so that the learning process becomes pleasant and effective (Oliveira, 2016). When teachers arrange practical and playful activities for environmental awareness, students show better adherence and learning, causing positive effects on teachers, such as productivity and work satisfaction. The correct order of the physical environment and the appropriate choice of topics become essential for the good progress of academic activities, student engagement and program assimilation (Moura, Cribb, \& Jeovanio-Silva, 2016). First grades teachers seem to demonstrate more affection, support, and good mood than the last grades teachers. Interactions between teachers and students, where the teacher values more affectionate behaviors and support to their students, can induce better students' performance in the execution of academic activities (Leite \& Colombo, 2008).

In this study, correlations between IHSE, depression and anxiety symptoms were not statistically significant. Between the IHSE and RSES scores, weak and positive correlations were identified, in particular with "Cultivate affection, support and good mood", "Approve and value behaviors", and "Disapprove, restrict and correct behaviors".

A good performance of the skills addressed in the "Cultivate affection, support and good mood" and "Approve and value behaviors" factors may indicate that the teachers have feelings of professional fulfillment and develop a good relationship with the students (Leite \& Colombo, 2008; El Achkar, Leme, Soares, \& Yunes, 2016). The factor "Disapprove, restrict and correct behavior" indicates that good self-esteem is necessary to cope with situations that require more assertiveness (Lopes, Dascanio, Ferreira, Del Prette, \& Del Prette, 2017).

\section{Conclusion}

First grades teachers showed more depressive symptoms, and higher scores in 
some IHSE factors (namely, Choosing and making available materials and content, Organizing physical environment, Cultivating affection, support and good mood, and total ESS score), suggesting better ESS. On the other hand, the self-esteem score was higher in the last grade teachers. Moderate and negative correlations were found between depression and anxiety symptoms and self-esteem, and a weak and positive correlation between self-esteem, and IHSE factors: "Cultivating affection, support and good mood", "Approve and value behaviors" and "Disapprove, restrict and correct behaviors".

It is important to look for the mental health of teachers in basic education. This phase is important in the educational process because it gives an important base for the following years, as in educational way as in emotional life. Many experiences in this phase may be remarkable for the children; thus, a proper educational social skill and an adequate mental health for teachers are essential for good educational work. Professionals in mental health can provide ways to improve these aspects of teachers.

The difference in the scores among both groups (A and B) suggests that future teacher research should consider specific teaching characteristics: first and last grades deal with different aspects and needs from the child development, which may impact teachers in different ways. Besides, future research can compare the educational social skills of public and municipal teachers to check if there is a difference between both groups, contributing to a broader understanding of how ESS develop and manifest in different educational contexts. These studies may also provide information to the development of interventions that can improve educational context.

\section{Conflicts of Interest}

The authors declare no conflicts of interest regarding the publication of this paper.

\section{References}

American Psychiatric Association (APA) (2014). DSM-5: Manual de Diagnóstico e Estatístico de Transtornos Mentais (5th ed.). Porto Alegre: Artmed.

Bartram, B., \& Bailey, C. (2009). Different Students, Same Difference? A Comparison of UK and International Students' Understandings of Effective Teaching. Active Learning in Higher Education, 10, 172-184. https://doi.org/10.1177/1469787409104903

Batista, J. B. V., Carlotto, M. S., \& Moreira, A. M. (2013). Depressão como Causa de Afastamento do Trabalho: Um Estudo com Professores do Ensino Fundamental. Psico, 44, 257-262.

Biaggio, A., Natalício, L., \& Spielberger, C. (1977). Desenvolvimento da forma experimental em português do Inventário de Ansiedade Traço-Estado (IDATE) de Spielberger. Arquivos Brasileiros De Psicologia Aplicada, 29, 31-44.

Bolsoni-Silva, A. T. (2010). Habilidades Sociais educativas do professor e sua relação com o repertório comportamental de crianças. Em: V. L. M. F., Capellini, \& O. M. P. R., Rodrigues (Orgs.), Práticas pedagógicas inclusivas: Da criatividade à valorização das diferenças (Vol. 5, pp. 147-181). Bauru: UNESP/FC/MEC. 
Caballo, V. E., \& Claudino, M. D. (2007). Manual de técnicas de terapia e modificação do comportamento. Santos.

Castro, M. M. C., Quarantini, L. C., Daltro, C., Pires-Caldas, M., Koenen, K. C., Kraychete, D. C. \& Oliveira, I. R. (2010). Comorbidade de sintomas ansiosos e depressivos em pacientes com dor crônica e o impacto sobre a qualidade de vida. Revista Psiquiatria Clínica, 38, 126-129. https://doi.org/10.1590/S0101-60832011000400002

Cornell, D., Shukla, K., \& Konold, T. R. (2016). Authoritative School Climate and Student Academic Engagement, Grades, and Aspirations in Middle and High Schools. AERA Open, 2, 1-18. https://doi.org/10.1177/2332858416633184

Dalgalarrondo, P. (2019). Psicopatologia e semiologia das transtornos mentais (3rd ed.). Porto Alegre: Artmed.

Dancey, C., \& Reidy, J. (2013). Estatística Sem Matemática para Psicologia. Porto Alegre: Penso.

Del Prette, A., \& Del Prette, Z. A. P. (1999). Psicologia das habilidades sociais: Terapia e educação (2nd ed.). Petrópolis: Vozes.

Del Prette, Z. A. P., \& Del Prette, A. (2013). Inventário de habilidades Sociais Educativas-versão Professor (IHSE-Prof): Dados psicométricos preliminares. Não publicado.

Diehl, L., \& Marin, A. H. (2016). Adoecimento mental em professores brasileiros: Revisão sistemática da literatura. Estudos Interdisciplinares em Psicologia, 7, 64-85.

https://doi.org/10.5433/2236-6407.2016v7n2p64

El Achkar, A. M. N., Leme, V. B. R., Soares, A. B., \& Yunes, M. A. M. (2016). Correlações entre Habilidades Sociais Educativas dos Professores, Burnout e Relação Professor-Aluno. Estudos e Pesquisas em Psicologia, 16, 873-891.

https://doi.org/10.12957/epp.2016.32890

Fernandes, C. S., Falcone, E. M. O., \& Sardinha, A. (2012). Deficiências em habilidades sociais na depressão: Estudo comparativo. Psicologia: Teoria e prática, 14, 183-196.

Ferreira, A. G., \& Moreira, J. A. M. (2010). A auto-estima profissional dos professores de educação física em Portugal. Exedra, 4, 65-80.

Ferreira, V. R. T. (2012). Levantamento da Intensidade de Sintomas Depressivos-LIS-D. Passo Fundo: Não publicado.

Ferreira, V. R. T. (2015). Levantamento da Intensidade de Sintomas de Ansiedade-LIS-A. Passo Fundo: Não publicado.

Freitas, L. G., \& Facas, E. (2013). Vivência de prazer-sofrimento no contexto de trabalho dos professores. Estudos e Pesquisas em Psicologia, 13, 7-26. https://doi.org/10.12957/epp.2013.7880

Gasparini, S. M., Barreto, S. M., \& Assunção, A. A. (2006). Prevalência de transtornos mentais comuns em professores da rede municipal de Belo Horizonte, Minas Gerais, Brasil. Cadernos de Saúde Pública, 22, 2679-2691. https://doi.org/10.1590/S0102-311X2006001200017

Huang, F. L., Eddy, C. L., \& Camp, E. (2017). The Role of the Perceptions of School Climate and Teacher Victimization by Students. Journal of Interpersonal Violence, 1-26. https://doi.org/10.1177/0886260517721898

Hutz, C. S., \& Zanon, C. (2011). Revisão da adaptação, validação e normatização da escala de autoestima de Rosenberg. Avaliação Psicológica: Interamerican Journal of Psychological Assessment, 10, 41-49.

Hutz, C. S., Zanon, C., \& Vazquez, A. C. S. (2014). Escala de autoestima de Rosenberg, In: C. S. Hutz (Org.), Avaliação em psicologia positiva (Vol. 7, pp. 85-94). Porto Alegre: 
Artmed.

Kernis, M. H. (2005). Measuring self-Esteem in Context: The Importance of Stability of Self-Esteem in Psychological Functioning. Journal of Personality, 73, 1569-1605. https://doi.org/10.1111/j.1467-6494.2005.00359.x

Kraft, M. A., Marinell, W. H., \& Shen-Wei Yee, D. (2016). School Organizational Contexts, Teacher Turnover, and Student Achievement: Evidence from Panel Data. American Educational Research Journal, 53, 1411-1449. https://doi.org/10.3102/0002831216667478

Leite, A. F. V. S., \& Carneiro, M. C. (2019). Como pedagogos atuantes ensinam ciências naturais nos anos iniciais do ensino fundamental. Geografia: Ambiente, Educação e Sociedades-GeoAmbES, 1, 158-172.

Leite, S. A. S., \& Colombo, F. A. (2008). A afetividade na mediação do professor da pré-escola. Revista de Psicologia da UNESP, 7, 12-29.

Lessa, T. C. R., Felicio, N. C., \& Almeida, M. A. (2017). Práticas Pedagógicas e Habilidades Sociais: Possibilidade de Pesquisa de Intervenção com Professores. Psicologia Escolar e Educacional, 21, 167-174. https://doi.org/10.1590/2175-3539201702121096

Levy, G. C. T. M., Nunes Sobrinho, F. P., \& Souza, C. A. A. (2009). Síndrome de Burnout em professores da rede pública. Produção, 19, 458-465. https://doi.org/10.1590/S0103-65132009000300004

Lopes, D. C., Dascanio, D., Ferreira, B. C., Del Prette, Z. A. P., \& Del Prette, A. (2017). Treinamento de Habilidades Sociais: Avaliação de um Programa de Desenvolvimento Interpessoal Profissional para Universitários de Ciências Exatas. Interação em psicologia, 21, 55-65.

Manso, D. S. S., \& Matos, M. G. (2006). Depressão, ansiedade e consumo de substâncias em adolescentes. Revista Brasileira de Terapias Cognitivas, 2, 73-84. https://doi.org/10.5935/1808-5687.20060008

Miranda, M. B. (2017). Saúde emocional de professores das escolas estaduais de Juiz de Fora-MG: Depressão e burnout. Dissertação de mestrado, Juiz de Fora: Universidade federal de Juiz de Fora.

Monteiro, M. A. A., \& Teixeira, O. P. B. (2004a). Uma análise das interações dialógicas em aulas de ciências nas séries iniciais do ensino fundamental. Investigações em Ensino de Ciências, 9, 243-263.

Monteiro, M. A. A., \& Teixeira, O. P. B. (2004b). O ensino de física nas séries iniciais do ensino fundamental: Um estudo das influências das experiências docentes em sua prática em sala de aula. Investigações em Ensino de Ciências, 9, 7-25.

Moreira, S. N. T., Melo, C. O. M., Tomaz, G., \& Azevedo, G. D. (2006). Estresse e ansiedade em mulheres inférteis. Revista Brasileira de Ginecologia e Obstetrícia, 28, 358-364. https://doi.org/10.1590/S0100-72032006000600007

Mosquera, J. J. M., \& Stobäus, C. D. (2006). Auto-imagem, auto-estima e auto-realização: Qualidade de vida na universidade. Psicologia, saúde \& doenças, 7, 83-88.

Moura, J. S. T., Cribb, S. L. S. P., \& Jeovanio-Silva, A. L. (2016). Vivência de atividades práticas e lúdicas na educação ambiental de crianças de 4-5 anos: O despertar da consciência ecológica e estímulo à motivação profissional e interação aluno-professor. $R e$ vista Brasileira de educação ambiental, 11, 361-384. https://doi.org/10.34024/revbea.2016.v11.1932

Oliveira, A. T. E. (2016). A mediação do professor e do material didático no Processo Ensino-aprendizagem de Matemática. Evidência, 12, 137-146. 
Pedro, N., \& Peixoto, F. (2006). Satisfação profissional e auto-estima em professores dos $2 .^{\circ}$ e 3..$^{\circ}$ ciclos do Ensino Básico. Análise Psicológica, 24, 247-262. https://doi.org/10.14417/ap.167

Pinheiro, M. N., Sousa, W. D. C., Feitosa, J. R. T., \& Batista, E. C. (2017). Identificação e compreensão de sintomas depressivos na infância em contexto escolar: Desafios contemporâneos do educador. Revista Pedagógica, 19, 155-171.

https://doi.org/10.22196/rp.v19i40.3748

Pyhältö, K., Pietarinen, J., \& Soini, T. (2015). When Teaching Gets Tough-Professional Community Inhibitors of Teacher-Targeted Bullying and Turnover Intentions. Improving Schools, 18, 263-276. https://doi.org/10.1177/1365480215589663

Ramos, L. B. C., \& Rosa, P. R. S. (2008). O ensino de ciências: fatores intrínsecos e extrínsecos que limitam a realização de atividades experimentais pelo professor dos anos iniciais do ensino fundamental. Investigações em Ensino de Ciências, 13, 299-331.

Reis, V. T. C., Prata, M. A. R., \& Soares, A. B. (2012). Habilidades sociais e afetividade no contexto escolar: Perspectivas envolvendo professores e ensino-aprendizagem. Psicologia Argumento, 30, 347-357.

https://doi.org/10.7213/psicolargum.v30i69.23290

Rodrigues, K. G. F. C., \& Santos, C. R. N. (2017). Readaptação dos Professores em Bibliotecas Escolares Públicas no Brasil: Uma Reflexão Psicológica sobre a Autoestima. Id on Line Revista Multidisciplinar e de Psicologia, 11, 281-304. https://doi.org/10.14295/idonline.v11i34.689

Rodrigues, M. F., \& Ferreira, S. A. D. (2016). A importância da leitura nas séries iniciais do ensino fundamental. Revista Mosaico, 7, 26-33.

Rosa, C. W., Perez, C. A. S., \& Drum, C. (2007). Ensino de física nas séries iniciais: Concepções da prática docente. Investigações em Ensino de Ciências, 12, 357-368.

Rosin-Pinola, A. R., Marturano, E. M., Elias, L. C. S., \& Del Prette, Z. A. P. (2017). Ensinando habilidades sociais educativas para professores no contexto da inclusão escolar. Revista Educação Especial, 30, 737-750. https://doi.org/10.5902/1984686X28430

Sadock, B. J., Sadock, V. A., \& Ruiz, P. (2016). Compêndio de Psiquiatria: Ciência do Comportamento e Psiquiatria Clínica. Porto Alegre: Artmed.

Salgado Júnior, A. P., \& Novi, J. C. (2016). Práticas de Gestão e Destinação dos Recursos Financeiros em Secretarias Municipais da Educação e Escolas Públicas Municipais de Ensino Fundamental. Desenvolvimento em Questão, 14, 330-362.

https://doi.org/10.21527/2237-6453.2016.33.330-362

Senler, B. (2016). Pre-Service Science Teachers' Self-Efficacy: The Role of Attitude, Anxiety and Locus of Control. Australian Journal of Education, 60, 26-41. https://doi.org/10.1177/0004944116629807

Serafim, A. P \& Saffi, F. (2015). Neuropsicologia Forense. In Quadros Depressivos (pp. 162-169). Porto Alegre: Artmed.

Silva, D. A., Aznar-Farias, M., \& Silvares, E. F. M. (2009). Influência do Treino em Habilidades Sociais na relação professor-aluno: Uma contribuição psicopedagógica para professores. Acolhendo a Alfabetização em Países de Língua Portuguesa, 3, 68-90. https://doi.org/10.11606/issn.1980-7686.v3i5p68-90

Silva, M. E. P. (2006). Burnout: Por que sofrem os professores? Estudos e pesquisas em psicologia, 6, 89-98.

Silva, N. R., Bolsoni-Silva, A. T., \& Loureiro, S. R. (2018). Burnout e depressão em professores do ensino fundamental: Um estudo correlacional. Revista Brasileira de Edu- 
cação, 23, 2-18. https://doi.org/10.1590/s1413-24782018230048

Silva, R. A. O., \& Guillo, L. A. (2015). Trabalho docente e saúde: Uam estudo com professores da educação básica do sudoeste goiano. Revista eletrônica da pós-graduação em educação UFG, 11, 1-17.

Silveira, D. X., \& Jorge, M. R. (1998). Propriedades psicométricas da escala de rastreamento populacional para depressão CES-D em populações clínica e não clínica de adolescentes e adultos jovens. Revista Psiquiatria Clinica, 25, 251-261.

Streider, R. (2009). Depressão e ansiedade em profissionais da educação das regiões da Amerios e da AMEOSC. Roteiro, 34, 243-268.

Teixeira, C. M., Nunes, F. M. S., Ribeiro, F. M. S., Arbinaga, F., \& Vasconcelos-Raposo, J. (2016). Atividade física, autoestima e depressão em idosos. Cuadernos de Psicología del Deporte, 16, 55-65.

Tostes, M. V., Albuquerque, G. S. C., Silva, M. J. S., \& Petterle, R. R. (2018). Sofrimento mental de professores do ensino público. Saúde em Debate, 42, 87-99. https://doi.org/10.1590/0103-1104201811607

Van Maele, D., \& Van Houtte, M. (2009). Faculty Trust and Organizational School Characteristics: An Exploration across Secondary Schools in Flanders. Educational Administration Quarterly, 45, 556-589. https://doi.org/10.1177/0013161X09335141 